\title{
ACRL Candidates, 1981 Elections
}

The listing for each of the following candidates includes the title, institution, and institutional address.

\section{Vice President / President Elect}

Richard A. Olsen, Director of the Library, Rhode Island College, $600 \mathrm{Mt}$. Pleasant Ave., Providence, RI 02908; Carla J. Stoffle, Assistant Chancellor for Educational Services, University of Wisconsin-Parkside, Wood Road, Kenosha, WI 53141 .

\section{BOARD OF DIRECTORS}

CJCLS Director-at-Large (1981-1985): Barbara Collinsworth. Associate Dean, Learning Resources, Macomb County Community College, 14500 Twelve Mile Road, Warren, MI 48093; James $O$. Wallace, Director of Learning Resources, San Antonio College, 1001 Howard St., San Antonio, TX 78284

CLS Director-at-Large (1981-1985): Dale K. Carrison, Director of Libraries, Mankato State University, Mankato, MN 56001: Willis M. Hubbard, Director, Hugh Stephens Library, Stephens College, Columbia, MO 65215.

ULS Director-at-Large (1981-1985): Betty L. Hacker, Colorado State University Libraries, Fort Collins, CO 80523; Sul H. Lee, Dean, University Libraries, The University of Oklahoma, Norman, OK 73019 .

Type-of-Activity Sections Council Director at Large (1981-1983): Donald F. Jay, Associate Director for Public Services, The New York Public Library, Fifth Ave. \& 42d St., New York, NY 10018; David R. McDonald, Systems Librarian, Green Library, Stanford University, Stanford, CA 94305 .

\section{ANTIIRopology \& SOCIOLOGY SECtION (ANSS)}

Vice-Chair/Chair-elect: Pamela Haas, Photographic Collection Librarian, American Museum of Natural History Library, Central Park West at $79 t h$ St., New York, NY 10024; Kenneth W. Parker, Curator of Social Science Collections, Stanford University Libraries, Stanford, CA 94305.

Secretary (two-year term): Sandra S. Kerbel, Reference-Bibliographer, John D. Williams Library, University of Mississippi, University, MS 38677; Cheryl C. Kugler, Cataloger, Lamont and Hilles Libraries, Harvard University, Cambridge, MA 02138.

Member-at-Large (two-year term): Ellen A Derey, Reference Librarian, Dickinson College
Library, Carlisle, PA 17013; Lynne M. Schmelz. Keil, Reference and Audiovisual Librarian, Dana Library, Rutgers University, 185 University Avenue, Newark, NJ 07102.

\section{ART SECTION (ARTS)}

Vice-Chair/Chair-elect: Floyd M. Zula, Head of Acquisitions, Captain John Smith Library, Christopher Newport College, 50 Shoe Lane. Newport News, VA 23606.

Secretary (two-year term): To be announced.

\section{Asian and African Section (AAS)}

Vice-Chair/Chair-elect: Merrv Burlingham, South Asia Librarian, Asian Collection, The General Libraries, The University of Texas at Austin, Austin, TX 78712; Francine H. McNulty, Middle Eastern Cataloger, Middle Eastern Department, Harvard College Library, Cambridge, MA 02138.

Member-at-Large (three-year term): John Yung-hsiang Lai, Associate Librarian, HarvardYenching Library, Harvard University, 2 Divinity Ave., Cambridge, MA 02138; Ryoko Toyama, Bibliographer/Cataloger for the Orientalia Collection, The Library, University of Oregon, Eugene, OR 97403 .

\section{Biblioghaphic INSTRuction Section (BIS)}

Vice-Chair/Chair-elect: Anne Roberts, Associate Librarian, State University of New York at Albany, Library 104, 1400 Washington Ave., Albany, NY 12222, Beth J. Shapiro, Coordinator, Social Science Collections \& Urban Policy \& Planning Librarian, Michigan State University Libraries, East Lansing, MI 48824.

Secretary (one-year term); Peter P. Olevnik, Head of Reference \& Coordinator of Bibliographic Instruction, Drake Memorial Library, SUNY College at Brockport, Brockport, NY 14420; Barbara A. Schwartz, Coordinator, Instructional Program, Undergraduate Library, University of Texas at Austin, Austin, TX 78712

Member-at-Large (one-year term): Carol F Ahmad, Head, Humanities Division, Oklahoma State University Library, Stillwater, OK 74074; Joan H. Worley, Reference Librarian, Undergraduate Library, University of Tennessee, Knoxville, TN 37916

Member-at-Large (three-year term): Karen S. Seibert, Head of Reference, The Library, University of Illinois at Chicago Circle, Box 8198, Chicago, IL 60680; Edward M. Walters, Director of Libraries, East Tennessee State University, 


\section{College Libraries Section (CLS)}

Vice-Chair/Chair-elect: Charles A. Gardner, Director. Perkins Library, Hastings College, Hastings, NE 68901; Thomas G. Kirk, Acting Director, Library/Learning Center, University of Wisconsin-Parkside, Kenosha, WI 53141.

Secretary (one-year term): Ronald R. Powell, Assistant Professor, School of Library Science, The University of Michigan, Ann Árbor, MI 48109: Joan Schwartz, Manager, Library Department, Cambridge University Press, 510 North Avenue, New Rochelle, NY 10801.

\section{Commlnity and Junior COllege. Libraries SECTION (CJCLS)}

Vice-Chair/Chair-elect: Sidney August, Director. Division of Educational Resources, Community College of Philadelphia, 34 S. 11th St., Philadelphia, PA 19107; Joseph F. Lindenfeld, Director of Library Services, Shelby State Community College, P.O. Box 40568, Memphis, TN 38104.

Secretary (one-year term): Damaris Ann Schmitt. Head of Reference, St. Louis Community College-Meramec, 11333 Big Bend Boulevard, Kirkwood, MO 63122; Colette A. Wagner, Circulation/Reserve/ILL Librarian, LaGuardia Community College Library, 31-10 Thomson Avenue. Long Island City, NY 11101.

\section{Education and Behatioral Sciences SECTION (EBSS)}

Vice-Chair/Chair-elect: Toyo S. Kawakami, Head. Social Work Library, Ohio State University, 1947 N. College Rd., Columbus, $\mathrm{OH} 43210$; Hannelore B. Rader, Director, Librarv/Learning Center, University of Wisconsin-Parkside, Kenosha. WVI 53141.

Secretary (two-year term): Mary Jane (Fowler) Neff. Social Sciences/Education Librarian and Information Specialist, William Allen White Library, Emporia State University, Emporia, KS 66801: Jean Thompson, Head, Social Science Division, University Libraries, Virginia Polytechnic Institute \& State University, Blacksburg, VA 24061 .

\section{Ltw' and Political Science Section (LPSS)}

Vice-Chair/Chair-elect: Robert Goehlert, Librarian for Economics and Political Science. Indiana University Library, Bloomington, IN 47405; Jacqueline M. Sellers, Law Cataloger, Texas Southern University, School of Law, Houston, TX 77004 .

Member-at-Large (one-year term): Deborah Ellis Dennis, Administrative Staff Librarian, University of Maryland Libraries, College Park, MD 20742; Marilyn Lutzker, Head of Reader Services, Library, John Jay College of Criminal Justice, 445 W. 59th St., New York, NY 10019.
Vice-Chair/Chair-elect: Joan M. Friedman, Curator of Rare Books, Yale Center for British Art, Box 2120 Yale Station, New Haven, CT 06520; Thomas F. Wright, Librarian, William Andrews Clark Library, 2520 Cimarron St., Los Angeles, CA 90018.

Secretary (two-year term): Marie E. Korey, Curator of Printed Books, The Library Company of Philadelphia, 1314 Locust Street, Philadelphia, PA 19107; Charles B. McNamara, Assistant Rare Book Librarian, Department of Rare Books, Cornell University Library, Ithaca, NY 14853.

Member-at-Large (three-year term): Donald Farren, Head, Special Collections Department, General Library, University of New Mexico, Albuquerque, NM 87131: Diana M. Thomas, Graduate School of Library \& Information Science, University of California, 405 Hilgard Avenue, Los Angeles, CA 90024.

\section{Science and Technology Section (STS)}

Vice-Chair/Chair-elect: Silvia Delgado Espinosa, Assistant Librarian, Central Reference Services, Louisiana State University, Baton Rouge, LA 70803; Charles L. Gilreath, Head, Automated Information Retrieval Service, Texas A\&M University Libraries, College Station, TX 77843.

Secretary (one-year term): Jan R. Kennedy, Chief, Lending Branch, Technical Information Systems, National Agricultural Library Building, Beltsville, MD 20705; Eleanor Mathews, Reference Librarian, Iowa State University Library Ames, IA 50011.

\section{Slavic and East El'ropean Section (SEES)}

Vice-Chair/Chair-elect: Miranda Beaven, Slavic Bibliographer. Wilson Library, University of Minnesota, Minneapolis, MN 55455; Tanja Lorković, Head of Cataloging Department, University of lowa Libraries, Iowa City, IA 52242.

Secretary (three-year term): Murlin Croucher. Slavic Bibliographer-Bibliographic Services, Wil son Library, University of North Carolinat. Chapel Hil], NC 27514; Marcella L. Stark, History Bibliographer, Area Studies, Bird Libran Syracuse University, Syracuse, NY 13210.

Member-at-Large (one-year term): Michaela Harnick, Cyrillic Cataloger, Columbia Universits Libraries, New York, NY 10027; James J. Maloney, The Library, University of Illinois at Chicago Circle, Box 8198, Chicago, IL 60634.

\section{University LibRaRies SEction (ULS)}

Vice-Chair/Chair-elect: Leo W. Cabell, Associate Director of Libraries, University of ColoradoBoulder, Norlin M450, Campus Box 184, Boulder, CO 80309; Kenneth G. Peterson, Dean of Library Affairs, Morris Library, Southern Illinois University, Carbondale, IL 62901. 


\section{Western European Specialists Section (WESS)}

Vice-Chair/Chair-elect: Charles S. Fineman, Humanities Bibliographer, Collection Planning Unit, University Library, University of CaliforniaSanta Cruz, Santa Cruz, CA 95064; Marcia Pankake, Bibliographer, 180 Wilson Library, University of Minnesota, 309 19th Ave. S., Minneapolis, MN 55455 .

Secretary (one-year term): James Campbell, Anglo-Germanic Bibliographer, Alderman Li-

\section{NEW CATALOGING MANUALS ARE IN PROGRESS}

A project to develop cataloging manuals for graphics, manuscripts, and motion pictures/ videorecordings has been undertaken cooperatively by the Library of Congress and the Joint Committee on Specialized Cataloging of the Council of National Library and Information Associations. The Joint Committee's participation in the project has been funded by a grant from the Research Resources Program of the National Endowment for the Humanities.

The project arose from a general feeling among concerned librarians that the special format mate- brary, Bibliography Section, University of Virginia, Charlottesville, VA 22901; Marianne Goldstein, State University of New York at Buffalo, Lockwood Library, Reference Department, Amherst, NY 14260.

Member-at-Large (one-year term): Martin Faigel, University of Alabama Library, P.O. Box S, University, AL 35486; Mary W. George, Head of Reference Division, Princeton University Library, Princeton, NJ 08540 .

rials are not adequately covered by the new edition of the Anglo-American Cataloging Rules (AACR 2).

Initial development of the manuals will be done at the Library of Congress. First drafts will be distributed by members of the Joint Committee to interested indivduals and organizations for review and comment. Three committees of specialists, one for each of the formats, will meet in Washington for a final review.

Librarians, archivists, and curators will benefit enormously by having standardized cataloging manuals for these materials, since no nationally recognized alternative exists. Those interested in the project should contact Elisabeth W. Betz, Picture Cataloging Specialist, Prints and Photographs Division, Library of Congress, Washington, DC 20540; (202) 287-5836.

\section{IF YOU'VE GOT A PROBLEM WE'RE JUST A (FREE) PHONE CALL AWAY!}

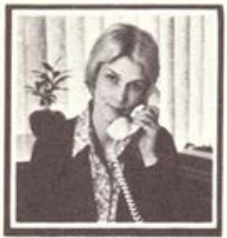

PHYLLIS HUTCHISON

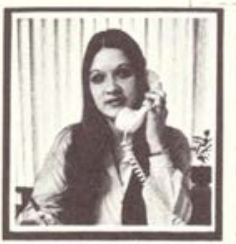

DANA LINDSEY

Phyllis and Dana are just two of Midwest Library Service's Personal Customer Service Representatives who are specially trained to solve any book ordering problem your library may encounter. Phyllis and Dana are thoroughly knowledgeable in all facets of the library jobber business, and if you are ever in need of their services, you can reach them by using our TOLL-FREE WATS Line, 1-800-325-8833 (Missouri customers please call COLLECT: 0-314-739-3100) for help in solving any problem. Your Customer Service Representative will follow the problem through to a satisfactory conclusion-without delay. Remember, Phyllis and Dana are "working" for you and your library. It's all part of Midwest Library Service's tradition of excellence.

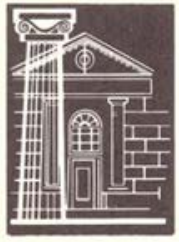

\section{"20 Years Of Service To College and University} Libraries" 


\section{Available for the first time on MICROFICHE}

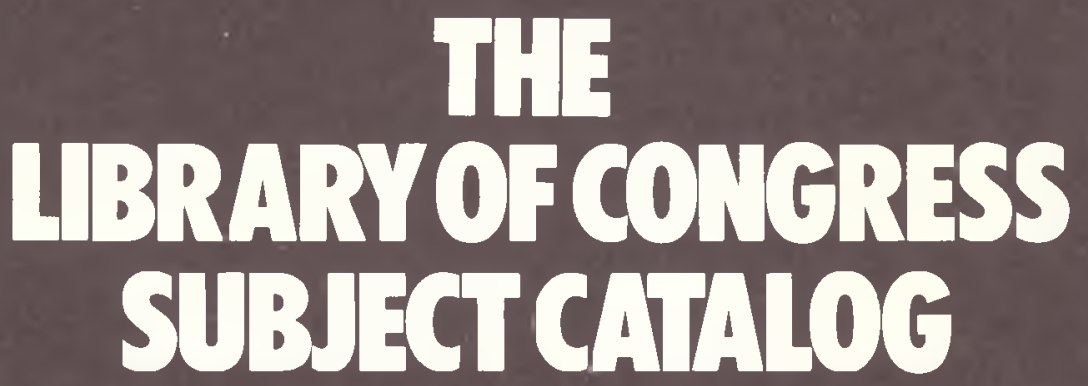

Current Subscription

An indispensable source for subject searching

(for less than a dollar a day)

ADVANCED LIBRARY SYSTEMS (ALS), a leading supplier of LC publications on microfiche, is now offering the 1981 CURRENT SUBSCRIPTION TO THE LC SUBJECT CATALOG.

The LC SUBJECT CATALOG contains entries for current books, pamphlets, periodicals and other serials, maps, and atlases arranged alphabetically by LC subject headings and alphabetically by author under the subject heading. Entries for belles lettres and imprints earlier than the current year and the two preceding years are included in the annual cumulation.

The subject headings and cross references in the Subject Catalog are taken from or are based on Library of Congress Subject Headings, its cumulative supplements, and the subject authority cards filed in the Official Catalog of the Library of Congress.

For complete information, call (617) $470-0610$ or use the coupon.

\begin{tabular}{c|l} 
ADVANCED LIBRARY \\
SYSTEMS INC. \\
93 Main Street. \\
$\begin{array}{l}\text { Andover. Mass 01810 } \\
\text { (617) 470-0610 }\end{array}$ \\
$\begin{array}{l}\text { Advanced Library Systems Inc. } \\
\text { 93 Main Street, Andover, Mass. 01810 } \\
\text { Please rush me complete information on ALS's Library of } \\
\text { Congress Subject Catalog on Microfiche. }\end{array}$ \\
\hline
\end{tabular}

